\title{
PENANGANAN KERAK PADA HANDLING EQUIPMENT MACHINE
}

\author{
Rizki Novianto $^{1}$
}

\begin{abstract}
ABSTRAK
Pengerakan Ferro karbonat tidak hanya fenomena kristalisasi yang terbentuk dalam proses alami (biomineralization), tetapi merupakan masalah yang sering ditemui dalam berbagai alat berat seperti bulldozer (Alice et al., 2011). Hal ini disebabkan karena terdapatnya unsur-unsur pembentuk kerak seperti besi dan karbonat dalam jumlah yang melebihi kelarutannya pada peralatan berat. Kerak biasanya mengendap dan tumbuh pada peralatan industri seperti pada pipa pipa hidrolik alat berat. Kerak merupakan suatu deposit dari senyawa-senyawa anorganik yang terendapkan dan membentuk timbunan kristal pada permukaan suatu subtansi. Kerak merupakan suatu deposit dari senyawa-senyawa anorganik yang terendapkan dan membentuk timbunan kristal pada permukaan suatu subtansi. Hal ini disebabkan karena terdapatnya unsur-unsur pembentuk kerak seperti alkalin, magnesium, kalsium, klorid, sulfat dalam jumlah yang melebihi kelarutannya pada keadaan kesetimbangan. Kerak biasanya mengendap dan tumbuh pada peralatan industri seperti cooling tower, heat exchangers, pipe, casing manifold, tank dan peralatan industri lainnya
\end{abstract}

Kata Kunci: Ferro carbonat, Kerak, Ferro Karbonat, Handling Equipment

\section{PENDAHULUAN}

Pengerakan Ferro karbonat tidak hanya fenomena kristalisasi yang terbentuk dalam proses alami (biomineralization), tetapi merupakan masalah yang sering ditemui dalam berbagai alat berat seperti bulldozer (Alice et dkk., 2011). Hal ini disebabkan karena terdapatnya unsur-unsur pembentuk kerak seperti besi dan karbonat dalam jumlah yang melebihi kelarutannya pada peralatan berat. Kerak biasanya mengendap dan tumbuh pada peralatan industri seperti pada pipa pipa hidolik alat berat. Kerak merupakan suatu deposit dari senyawa-senyawa anorganik yang terendapkan dan membentuk timbunan kristal pada permukaan suatu subtansi (Hisyam,dkk, 2013).

Ferro karbonat $\left(\mathrm{FeCO}_{3}\right)$ merupakan kerak yang terbentuk dalam proses alami dan menjadi masalah yang sering ditemui dalam pipa hidrolik pada alat berat (Akhyari ,dkk., 2012). Kerak merupakan suatu deposit dari senyawa-senyawa anorganik yang terendapkan dan membentuk timbunan kristal pada permukaan suatu subtansi. Hal ini disebabkan karena terdapatnya unsur-unsur pembentuk kerak

${ }^{1}$ Teknik Mesin Universitas Muhammadiyah Semarang 
seperti alkalin, magnesium, kalsium, klorid, sulfat dalam jumlah yang melebihi kelarutannya pada keadaan kesetimbangan. Kerak biasanya mengendap dan tumbuh pada peralatan industri seperti cooling tower, heat exchangers, pipe, casing manifold, tank dan peralatan industri lainnya (Alice dkk., 2011; Holyz ,dkk., 2004). (Isopecus ,dkk., 2010; Hisyam, 2013; Gourdon , dkk., 2011).

Potensi kerak yang disebabkan oleh kerak besi (II) karbonat dimiliki hampir semua jenis alat berat seperti bulldozer, backhoe, loader dan beberapa alat berat yang lain. Besi (II) karbonat membentuk padatan atau deposit yang sangat kuat menempel pada permukaan pipa hidrolik. Sejauh ini $\mathrm{FeCO}_{3}$ merupakan penyebab kerak pada beberapa sistem seperti pipa hidrolik alat berat (Tzotzi ,dkk., 2007; Amor dkk., 2004). Penyebab terjadi kerak di dalam pipa hidrolik akan mengurangi diameter serta menghambat aliran fluida pada sistem pipa tersebut, sehingga menimbulkan masalah terhambatnya aliran fluida. Terganggunya aliran fluida tersebut menyebabkan tekanan semakin tinggi, sehingga pipa mengalami kerusakan (Basim ,dkk., 2012).

Metode mengatasi pembentukan kerak di industri minyak dan gas biasanya dengan menerapkan bahan kimia yang dikenal sebagai inhibitor untuk mengontrol pertumbuhan kristalisasi $\mathrm{FeCO}_{3}$ dengan tujuan, mengurangi, mencegah atau menunda, pembentukan kerak $\mathrm{FeCO}_{3}$ (Alimi ,dkk., 2007; Azimi and Papangelakis, 2010; Rabizadeh,dkk., 2014). Inhibitor biasanya diinjeksikan kedalam larutan yang secara kontinyu maupun periodik metode ini mampu mengendalikan proses nucleation, pertumbuhan kristal $\mathrm{FeCO}_{3}$ yang terjadi pada permukaan pipa dan peralatan lainnya (Sediono, dkk., 2011; Ratna, 2011).

Kerak juga dapat dicegah menggunakan aditif asam tartrat sebagai inhibitor untuk mengontrol impurity senyawa organik serta komposisi morfologi dan fase kristal $\mathrm{FeCO}_{3}$ dan mencegah proses nucleation, pertumbuhan kristal $\mathrm{FeCO}_{3}$ (Muryanto .,dkk, 2014; Siswoyo dan Erna., 2005; Mullin, 2004). Hal-hal inilah yang mendasari untuk dilakukan suatu penelitian lebih lanjut mengenai inhibitor yang lebih efektif yaitu dengan inhibitor asam tartrat .

Oleh karena itu, pada penelitian ini menggunakan asam tartrat sebagai inhibitor diharapkan mampu menghambat laju pertumbuhan kerak magnesium karbonat yang terbentuk di dalam pipa-pipa industri. Penelitian ini juga mempelajari mengetahui perubahan fasa morfologi kristal dan pertumbuhan massa kerak. 


\section{METODOLOGI}

Bahan yang digunakan dalam penelitian ini meliputi:

- Larutan $\mathrm{Na}_{2} \mathrm{CO}_{3}$ dengan kosentrasi 3000 ppm dibuat dengan melarutkan kristal $\mathrm{Na}_{2} \mathrm{CO}_{3}$ (Natrium Carboant)grade : analitik

- Larutan $\mathrm{FeCl}_{2}$ dengan kosentrasi 3000 ppm dibuat dengan melarutkan kristal $\mathrm{FeCl}_{2}$ (Calcium Chloride Dihydrad)grade : analitik

- Asam tartrat $\mathrm{C}_{4} \mathrm{H}_{4} \mathrm{O}_{6}$ dengan konsentrasi 5 ppm, dengan melarutkan kristal asam tartrat grade analitik.

- Aquades

\section{Alat Eksperimen Pembentukan kerak}

Alat yang digunakan dalam penelitian ini adalah alat yang di rancang sendiri oleh peneliti terdahulu. Alat tersebut terdiri dari empat buah bejana yaitu dua bejana dibawah $(1,2)$ dengan kapasitas 6 liter dan dua bejana diatas $(3,4)$ dengan kapasitas 0,8 liter. Kegunaan bejana tersebut adalah untuk menampung larutan $\mathrm{FeCl}_{2}$ pada bejana 1 dan 3 dan larutan $\mathrm{Na}_{2} \mathrm{CO}_{3}$ pada bejana 2 dan 4 . Pada alat tersebut dipasang dua buah pompa yang digunakan untuk memompa larutan $\mathrm{FeCl}_{2}$ dari bejana $1 \mathrm{ke}$ bejana 3 dan larutan $\mathrm{Na}_{2} \mathrm{CO}_{3}$ dari bejana 2 ke bejana 4 . Permukaan larutan pada bejana 3 dan 4 dijaga agar keduanya mempunyai ketinggian yang sama dan dapat diatur naik atau turun guna mendapatkan perbedaan ketinggian permukaan dengan pengeluaran akhir dari rumah kupon sehingga dapat digunakan untuk mengatur laju aliran.

Larutan yang berada didalam bejana 3 dan 4 kemudian secara bersamaan dialirkan menuju kupon, selanjutnya larutan tersebut mengalir dan masuk kedalam bejana penampungan yang kemudian dibuang sebagai limbah. Didalam kupon-kupon larutan $\mathrm{FeCl}_{2}$ dan $\mathrm{Na}_{2} \mathrm{CO}_{3}$ bereaksi sehingga membentuk kerak. Kerak tersebut mengendap pada dinding-dinding kupon yang disebut sebagai kerak $\mathrm{FeCO}_{3}$. Penambahan asam tartrat dilakukan ketika larutan $\mathrm{FeCl}_{2}$ dan $\mathrm{Na}_{2} \mathrm{CO}_{3}$ bertemu di dalam pipa. 


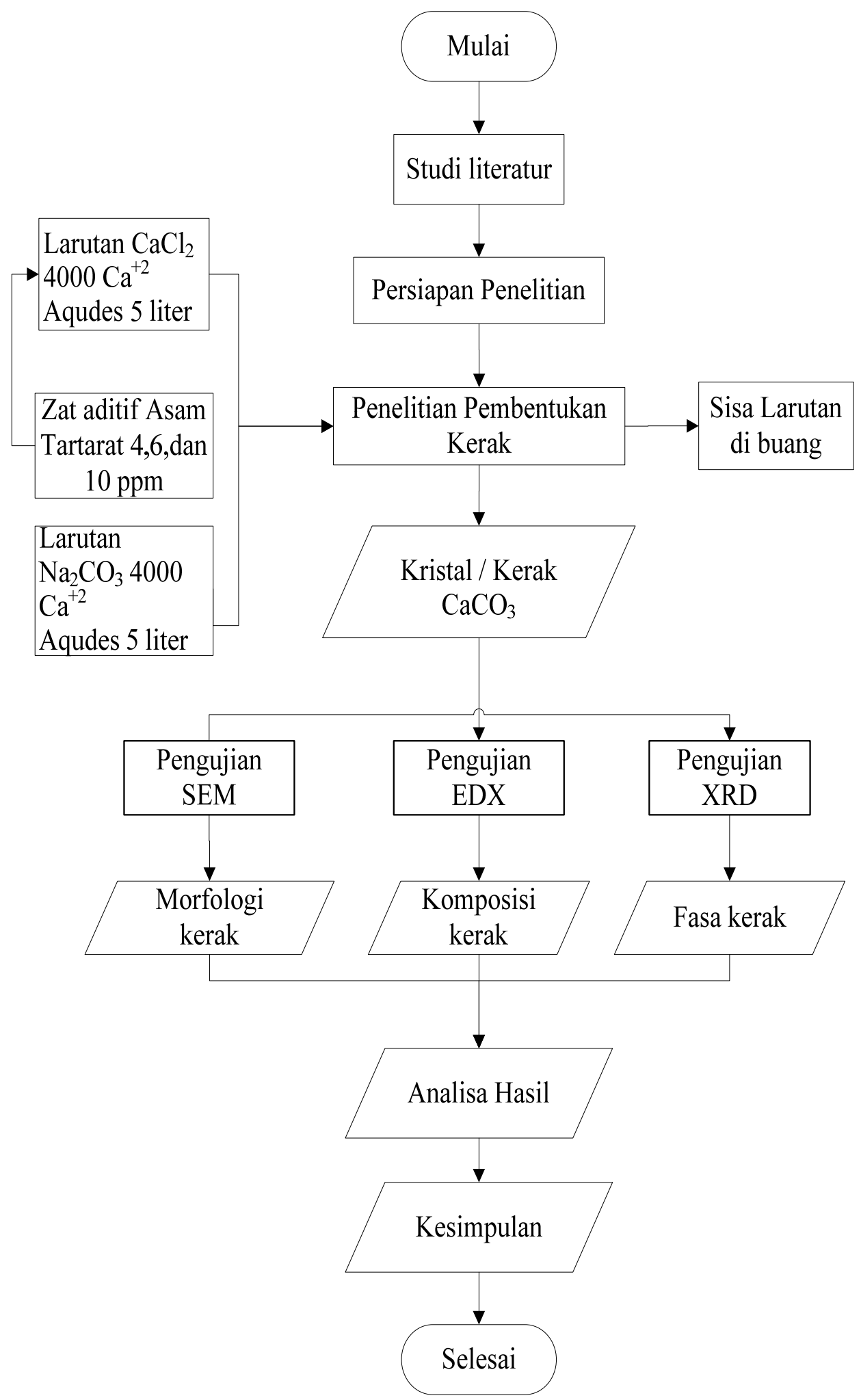

Gambar 1 Diagram Alir Penelitian 


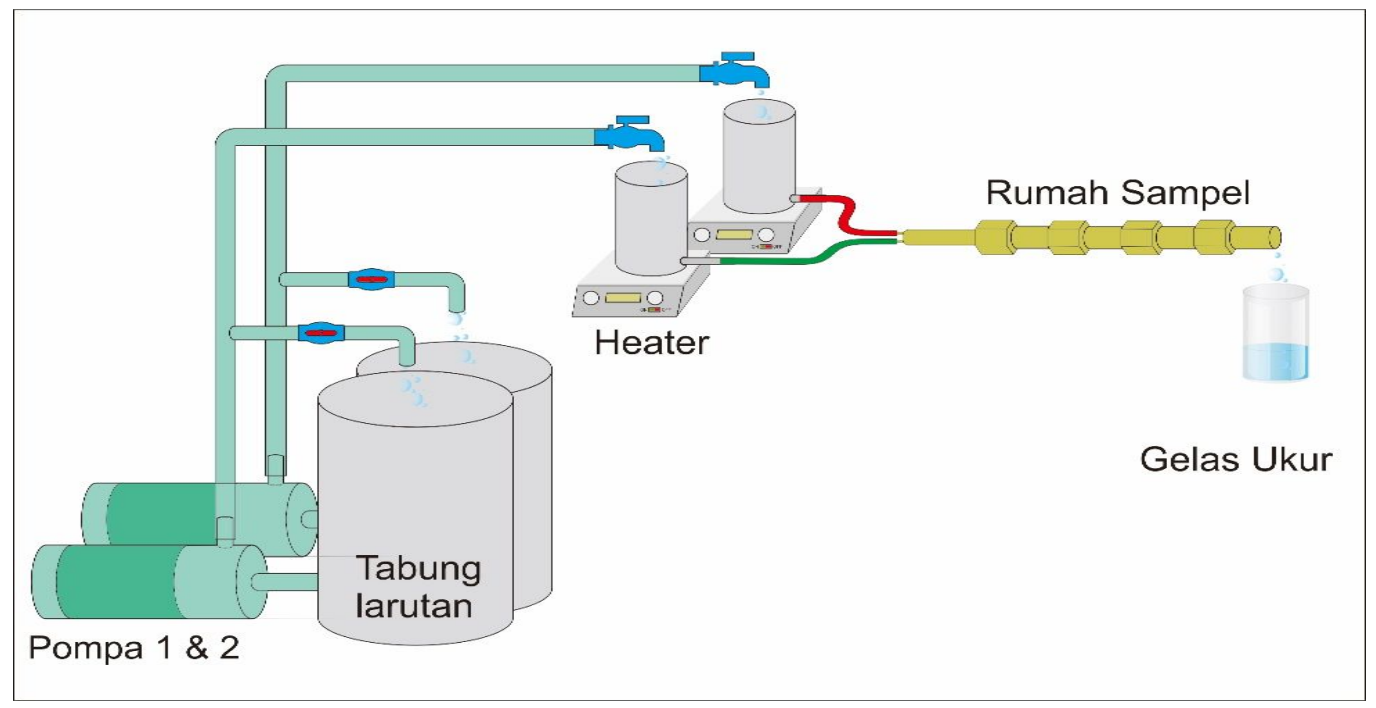

Gambar 2 Skema Closed Circuit Scale Simulator

\section{HASIL DAN PEMBAHASAN}

Pembentukan kerak $\mathrm{FeCO}_{3}$ pada penelitian ini dapat dilihat pada reaksi kimia larutan $\mathrm{CaCl}_{2}$ dengan $\mathrm{Na}_{2} \mathrm{CO}_{3}$ dibawah ini

$$
\mathrm{FeCl}_{2}+\mathrm{Na}_{2} \mathrm{CO}_{3} \longrightarrow \mathrm{FeCO}_{3}+2 \mathrm{NaCl}
$$

Untuk membuat larutan $\mathrm{FeCl}_{2}$ dengan $\mathrm{Na}_{2} \mathrm{CO}_{3}$ pertama-tama dilakukan perhitungan konsentrasi kalsium yang direncanakan yaitu 3000 ppm dengan laju alir sebesar $30 \mathrm{ml} / \mathrm{menit}$. Perhitungan pembuatan larutan diambil konsentrasi larutan 3000 ppm $\mathrm{Fe}^{2+}$.

Cara perhitungan kebutuhan zat dan larutan untuk percobaan dengan laju alir $30 \mathrm{ml} / \mathrm{menit}$.

- Waktu percobaan

- Laju alir larutan

- Volume larutan yang dibutuhkan (4x60x 25ml)

- Volume larutan $\mathrm{FeCl}_{2} 3000$ ppm $\mathrm{Fe}^{2+}$

- Volume larutan $\mathrm{Na}_{2} \mathrm{CO}_{3} 3000$ ppm Fe2+

- Volume larutan asam sitrat

$$
\begin{aligned}
& =1 \mathrm{jam} \\
& =30 \mathrm{ml} / \mathrm{menit} \\
& =6000 \mathrm{ml} \\
& =3000 \mathrm{ml} \\
& =3000 \mathrm{ml} \\
& =1000 \mathrm{ml}
\end{aligned}
$$

Setiap percobaan ada sisa larutan masing - masing ditabung atas sebanyak $800 \mathrm{ml}$ maka untuk memudahkan pembuatan larutan, kedua jenis larutan tersebut masing-masing disiapkan sebanyak $4000 \mathrm{ml}$ sehingga jumlah larutan yang dibutuhkan adalah : 
Volume larutan $\mathrm{FeCl}_{2}$ yang disiapkan

$=4000 \mathrm{ml}$

Volume larutan $\mathrm{Na}_{2} \mathrm{CO}_{3}$ yang disiapkan

$=4000 \mathrm{ml}$

Kedua larutan dibuat secara terpisah dengan cara melarutkan aquades dengan kristal $\mathrm{FeCl}_{2}$ dan $\mathrm{Na}_{2} \mathrm{CO}_{3}$.

Perhitungan kebutuhan larutan untuk laju alir $30 \mathrm{ml} / \mathrm{menit}$

Berat molekul (BM) $\mathrm{FeCl}_{2}$

$=116 \mathrm{~g} / \mathrm{mol}$

Berat Atom (BA) Fe

$=56$

Berat molekul (BM) $\mathrm{Na}_{2} \mathrm{CO}_{3}$

3000 ppm $\mathrm{Fe}^{2+}$

$=55,99 \mathrm{~g} / \mathrm{mol}$

$=3000 \mathrm{Fe} /$ liter

Untuk volume $4000 \mathrm{ml}$ atau 4 liter, kebutuhan $\mathrm{Fe}^{2+}$ adalah

$3000 \mathrm{Fe} /$ litert $\mathrm{x} 4 \mathrm{lt}=12.000 \mathrm{Fe}$

$=12$ gram

Sehingga $\mathrm{FeCl}_{2}$ yang dibutuhkan adalah

(116/ 56$)$ x 12 gram

$\mathrm{Mol} \mathrm{FeCl}_{2}: 24.86 / 116$

$=24.86$ gram

$=0,2 \mathrm{~mol}$

Karena equimolar maka kristal $\mathrm{Na}_{2} \mathrm{CO}_{3}$ yang dibutuhkan adalah

$0,2 \times 55,99$

$=11.198$ gram

Pembuatan larutan asam tartrat

Asam tartrat $5 \mathrm{ppm}=5 \mathrm{mg}$ dalam 1 liter

Dari hasil perhitungan seluruhnya dapat dimasukkan dalam tabel sehingga mudah untuk dijadikan pedoman pada saat pembuatan larutan. Setelah semua perhitungan yang diperlukan untuk pembuatan larutan selesai maka dilanjutkan untuk persiapan pembuatan larutan tesebut. Bahan dan peralatan yang diperlukan dalam pembuatan larutan adalah aquades, kristal $\mathrm{FeCl}_{2}$. kristal $\mathrm{Na}_{2} \mathrm{CO}_{3}$, kristal asam sitrat, timbangan analitik, gelas ukur, labu takar, pengaduk dan kertas saring.

Pembuatan larutan dimulai dengan menimbang kristal $\mathrm{FeCl}_{2}$ dan kristal $\mathrm{Na}_{2} \mathrm{CO}_{3}$ sesuai dengan hasil perhitungan. Langkah selanjutnya adalah memasukkan aquades sebanyak satu liter dan kristal $\mathrm{FeCl}_{2}$. kedalam bejana kemudian diaduk dan dilanjutkan lagi dengan memasukkan aquades kedalam bejana hingga volumenya mencapai lima liter dan diaduk lagi sampai merata. Setelah larutan tercampur merata maka dilakukan penyaringan dengan kertas saring 0,22 $\mu \mathrm{m}$. Sebelum digunakan larutan disimpan dalam bejana tertutup agar terhindar dari debu. Pembuatan larutan $\mathrm{Na}_{2} \mathrm{CO}_{3}$ dilakukan dengan cara yang sama seperti pada pembuatan larutan $\mathrm{FeCl}_{2}$. 
Pembentukan Besi (II) karbonat: $\mathrm{FeCl}_{2}+\mathrm{Na}_{2} \mathrm{CO}_{3} \rightarrow \mathrm{FeCO}_{3}+2 \mathrm{NaCl}$. Untuk membuat larutan $\mathrm{FeCl}_{2}$ dan $\mathrm{Na}_{2} \mathrm{CO}_{3}$, dilakukan perhitungan konsentrasi larutan dengan laju alir $30 \mathrm{~mL} / \mathrm{menit}$.

Pengambilan data (percobaan) dilakukan dengan penambahan aditif alumina 5 ppm. Larutan $\mathrm{Na}_{2} \mathrm{CO}_{3}$ dan $\mathrm{FeCl}_{2}$ masing-masing sebanyak empat liter dimasukkan masing-masing ke dalam bejana 1 dan bejana 2. Setelah itu pompa dihidupkan dan larutan naik mengisi sampai batas atas bejana 3 dan bejana 4, kemudian pompa dimatikan. Beberapa saat kemudian pompa dihidupkan kembali dan larutan mulai mengisi kupon, dengan demikian percobaan telah dimulai. Pencatatan waktu pada saat yang sama juga diaktifkan dimana setiap dua menit sekali perlu dilakukan pengukuran terhadap konduktivitas larutan. Untuk melakukan pengukuran konduktivitas larutan, larutan yang keluar dari kupon ditampung pada bejana kecil yang terbuat dari plastik dan sesegera mungkin elektroda conductivitymeter dimasukkan.

Konductivitymeter akan mengukur nilai konduktivitas larutan (pembacaan digital mulai berjalan dari nol kemudian naik sampai akhirnya berhenti). Angka yang terakhir inilah yang dicatat, dan seterusnya dilakukan berulang-ulang setiap dua menit. Setelah empat jam, pompa dihentikan dan saluran menuju kupon dilepas. Satu jam kemudian kupon diambil dari rumah kupon dan dikeringkan dalam oven dengan suhu $60^{\circ} \mathrm{C}$ selama dua belas jam. Penimbangan massa kerak dilakukan pada waktu kerak masih menempel pada kupon. Selanjutnya selisih massa kupon dengan kerak dikurangi massa kupon tanpa kerak adalah massa kerak itu sendiri.

Asam tartrat ditambahkan dalam proses pembentukan kerak dilakukan dengan tujuan untuk menghambat pertumbuhan kerak. Asam tartrat yang ditambahkan dalam penelitian ini adalah $5 \mathrm{ppm}$. Asam tartrat dipilih sebagai aditif untuk menghambat pertumbuhan kerak karena asam tartrat merupakan asam lemah yang memiliki daya hambat yang kuat terhadap pembentukan kerak dan ramah lingkungan. Penelitian dilakukan dengan membandingkan tanpa penambahan zat aditif dan penambahan asam tartrat $5 \mathrm{ppm}$. Pengaruh penambahan asam tartrat terhadap massa kerak $\mathrm{FeCO}_{3}$ ditunjukan pada Gambar 3.

Analisa yang dilakukan yaitu tentang waktu yang dibutuhkan oleh senyawa $\mathrm{FeCO}_{3}$ untuk membentuk inti kristal pertama kali. Waktu induksi ditandai dengan 
menurunnya nilai konduktivitas larutan secara tajam yang menandakan bahwa ion besi telah bereaksi dengan ion karbonat dan mengendap membentuk kerak. Waktu induksi untuk penambahan asam tartrat 5 ppm dan tanpa penambahan masingmasing menunjuhkan nilai yang berbeda dengan waktu penelitian pada penambahan ion asam tartrat 5 ppm dan tanpa penambah dengan kosentrasi larutan $\mathrm{Fe}^{2+} 3000$ ppm.

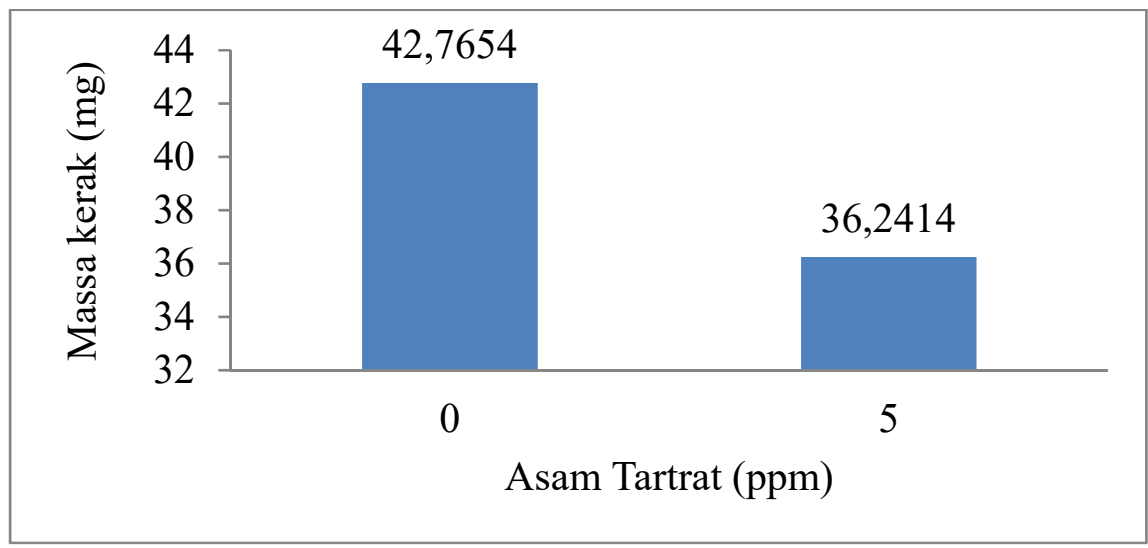

Gambar 3 .Grafik pengaruh asam tartrat 5 ppm terhadap massa kerak $\mathrm{FeCO}_{3}$

Waktu induksi untuk tanpa penambahan adalah 28 menit dengan nilai konduktivitas $8660 \mu \mathrm{S} / \mathrm{cm}$ sedangkan penambahan asam tartrat $5 \mathrm{ppm}$ memiliki waktu induksi 36 menit dengan nilai konduktivitas sebesar $8660 \mu \mathrm{S} / \mathrm{cm}$. Waktu tersebut merupakan waktu induksi dikarenakan ion larutan mulai bereaksi untuk membentuk inti kristal. Berdasarkan gambar tersebut asam tartrat 5 ppm mampu meningkatkan waktu induksi sebesar $22.2 \%$ dari waktu induksi tanpa penambahan aditif.

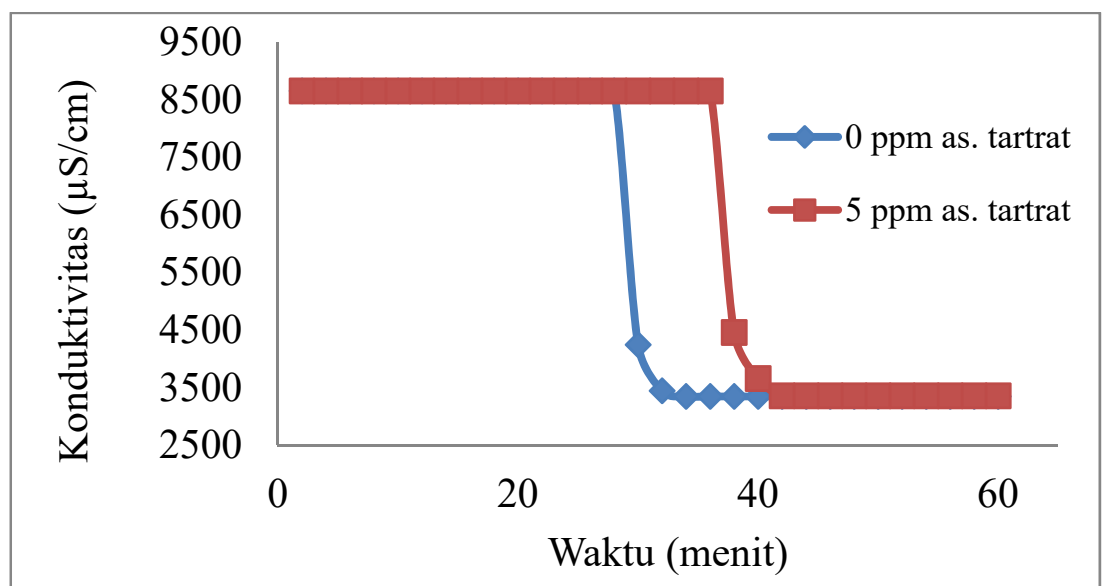

Gambar 4 . Pengaruh Asam Tartrat 5 ppm terhadap Massa Kerak FeCO3 


\section{Pengujian SEM}

Pengujian morphology bisa dilakukan pada suatu instrumen yaitu dengan mengunakan perangakat SEM. Pengujian SEM dilakukan untuk mengkaji morfologi kristal untuk membuktikan bahwa ada perubahan morphology kerak akibat penambahan asam tartrat 5 ppm. Kajian morfologi adalah kajian yang meliputi kekasaran kristal, ukuran kristal, bentuk kristal, proses pengintian serta fenomena pembentukan kristal.

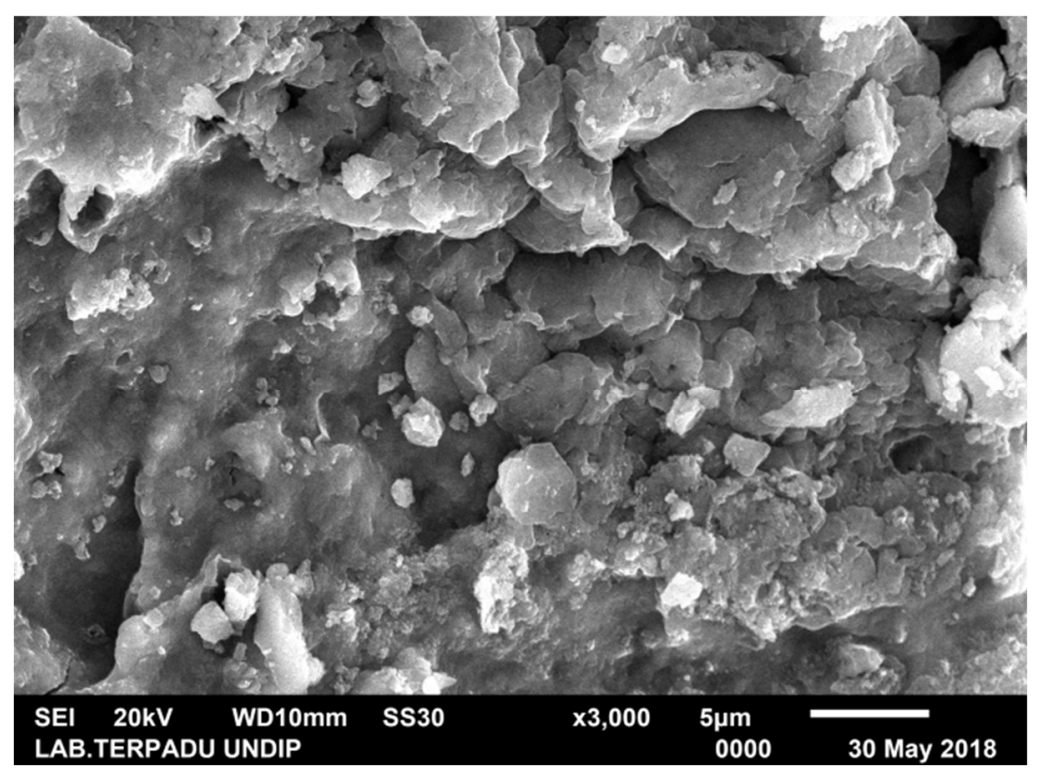

Gambar 5 Morfologi Kerak Magnesium Karbonat Hasil Percobaan Tanpa Penamban Zat Aditif

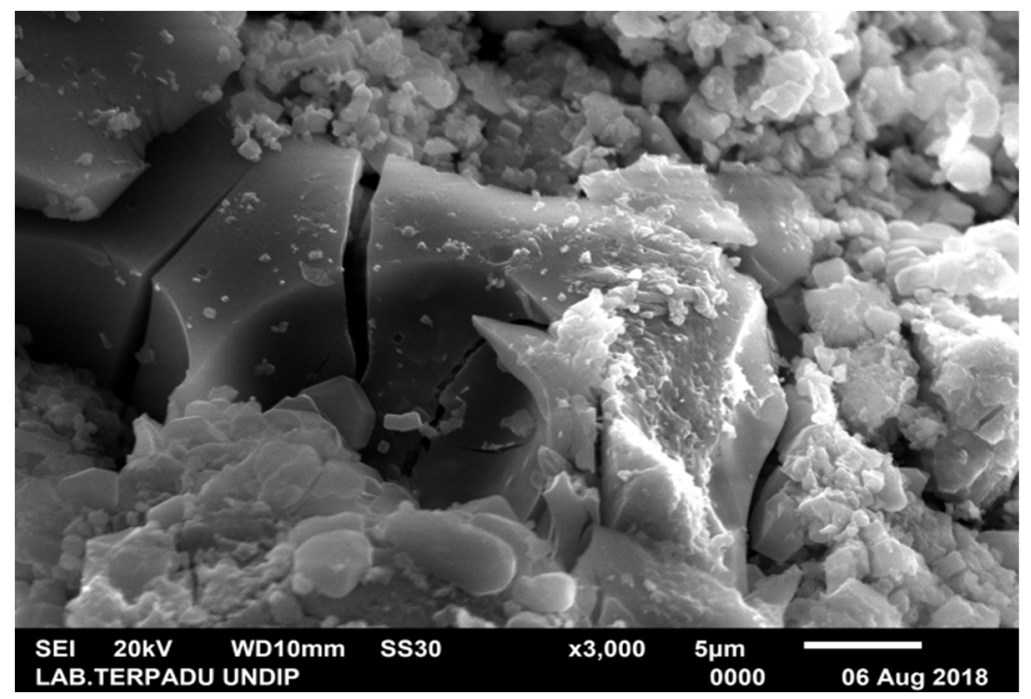

Gambar 6 .Morfologi Kerak Magnesium Karbonat Hasil Percobaan Dengan

Penambahan Aditif Asam Tartrat 5 Ppm 
Gambar 5 dan 6 menunjukan hasil uji SEM (a) tanpa penambahan dan (b) dengan penambahan asam tartrat $5 \mathrm{ppm}$. Hasil SEM menunjukan perubahan bentuk kristal dari plate siderit (tanpa penambahan) menjadi bentuk yang menggumpal. Hal ini disebabkan asam tartrat dapat menghambat pembentukan kerak $\mathrm{FeCO}_{3}$ secara mekanik dan kimiawi. Secara kimiawi, asam tartrat merupakan senyawa asam lemah yang mampu menguraikan kerak $\mathrm{FeCO}_{3}$. Selain itu, asam tartrat dapat bereaksi dengan molekul ferro karbonat menjadi molekul lain yang lebih mudah untuk dibersihkan (Holysz et al., 2007).

\section{Pengujian EDS}

Pada prinsipnya mikroskop elektron dapat mengamati morfologi, struktur mikro, komposisi, dan distribusi unsur. Untuk menentukan komposisi unsur secara kualitatif dan kuantitatif perlu dirangkaikan satu perangkat alat EDS (Energy Dispersive X-ray Spectrometer). Hasil Pengujian EDS hasil percobaan pada laju alir $30 \mathrm{~mL} / \mathrm{menit}$ pada konsentrasi 3000 ppm dapat dilihat pada Gambar 7 dan 8 .

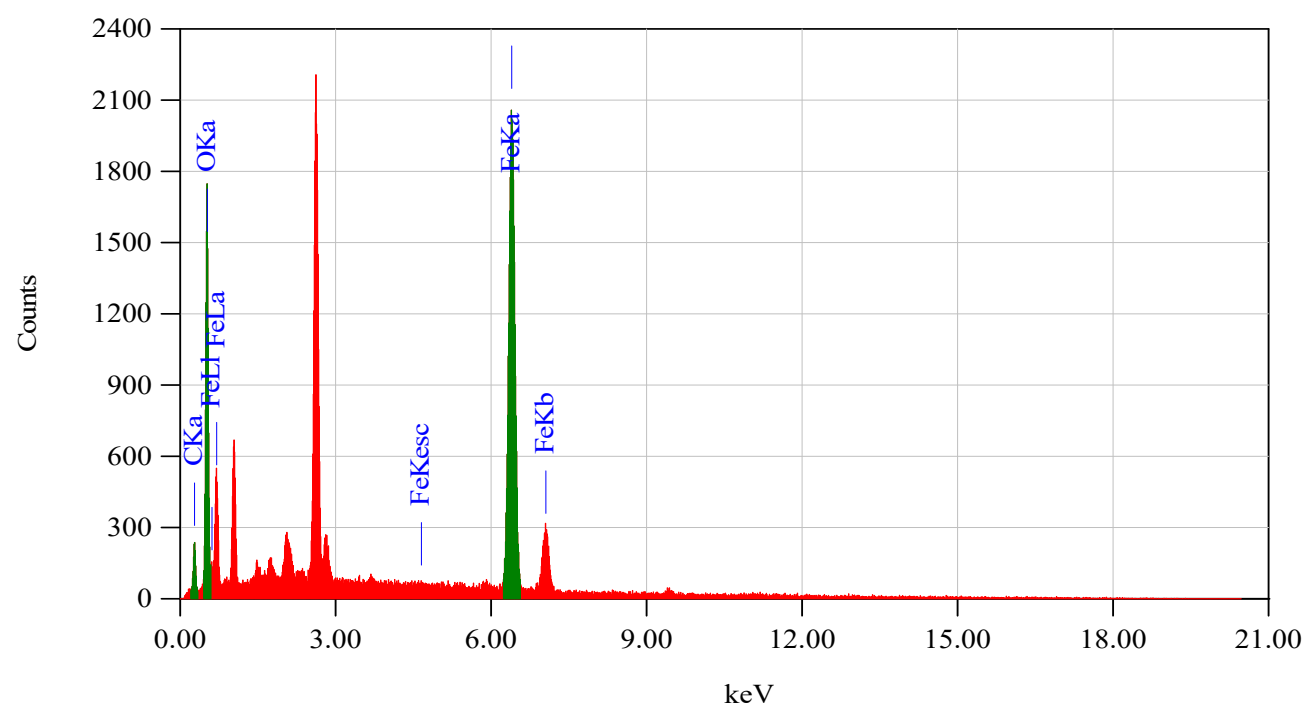

Gambar 7 Hasil Analisis $\mathrm{EDS} \mathrm{FeCO}_{3}$ tanpa Penambahan

Tabel 1. Hasil Analisa Mikro Kristal FeCO3 Tanpa Penambahan

\begin{tabular}{|c|c|}
\hline Element & $W t \%$ \\
\hline$C K$ & 16.7 \\
\hline$O K$ & 18.55 \\
\hline$F e K$ & 64.75 \\
\hline
\end{tabular}


Sedangkan untuk Hasil Pengujian EDS hasil percobaan pada penambahan asam tartrat 5 ppm dengan laju alir $30 \mathrm{~mL} /$ menit dan konsentrasi larutan 3000 ppm dapat dilihat pada Gambar 8.

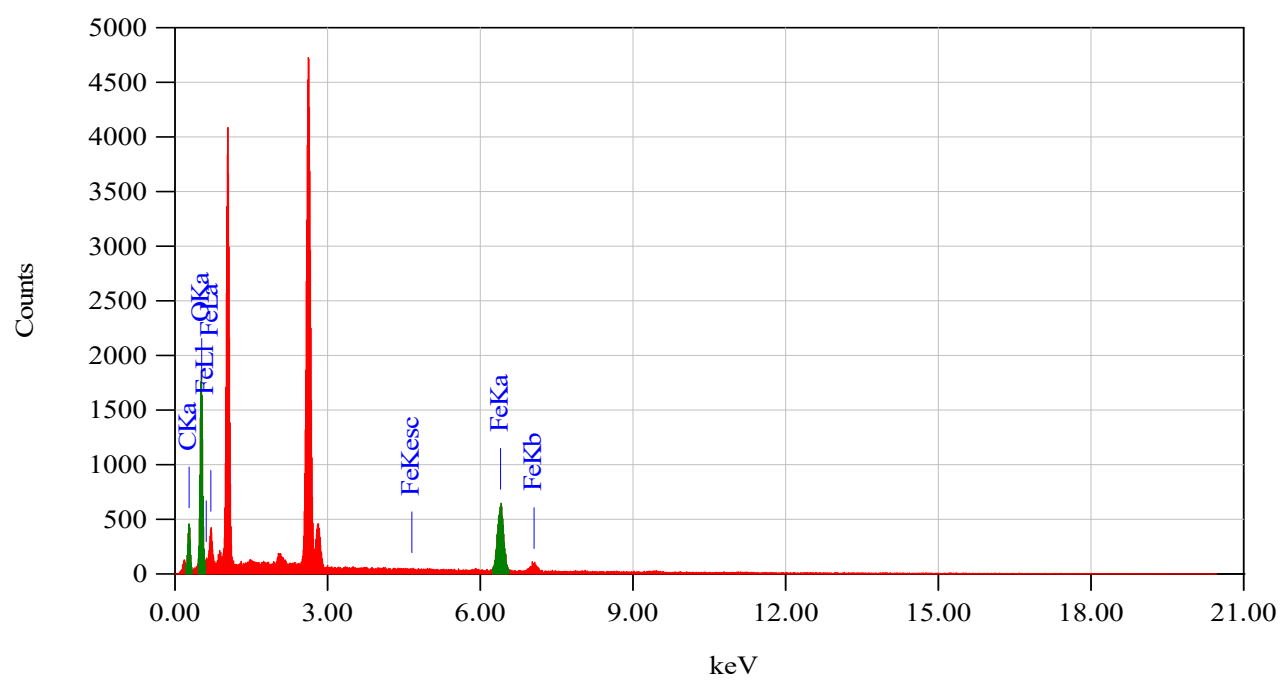

Gambar 8. Gambar Hasil Analisis $\mathrm{EDS} \mathrm{FeCO}_{3}$ dengan asam tartrat 5 ppm

Tabel 2. Hasil analisa mikro kristal $\mathrm{FeCO}_{3}+$ asam tartrat 5 ppm

\begin{tabular}{|c|c|}
\hline Element & $W t \%$ \\
\hline$C K$ & 49.68 \\
\hline$O K$ & 11.21 \\
\hline$F e K$ & 39.12 \\
\hline
\end{tabular}

Hasil analisa mikro meliputi komposisi atom pembentuk kristal yang dinyatakann dalam presentse atom. Presentase diatas bila dibandingkan dengan hitungan secara teoritis ternyata mempunyai perbedaan.

Menurut perhitungan teoritis presentase berat kandungan $\mathrm{Fe}$ pada $\mathrm{FeCO}_{3}$ seharusnya adalah $56 / 100 \times 100 \%=56 \%$ sedangkan hasil analisa mikro dengan kandungan $\mathrm{Fe}$ tanpa penambahan $=64.75 \%$ sedangkan pada penambahan asam tartrat 5 ppm adalah 39.12\%. Untuk kadar carbon (C) seharusnya 12/100 x 100\%= $12 \mathrm{wt} \%$ sedangkan hasil analisa mikro didapatkan tanpa penambahan $=16.7 \%$ 
sedangkan pada penambahan asam tartrat $5 \mathrm{ppm}=49.68 \%$. Untuk kadar oksigen seharusnya $16 / 100 \times 100 \%=16 \%$ sedangkan hasil analisa mikro tanpa penambahan $=18.55 \%$ sedangkan pada penambahan asam tartrat $5 \mathrm{ppm}=11.21 \%$.

Perbedaan hasil analisa mikro ini di akibatkan oleh beberapa sebab yaitu :

1. Adanya konsentrasi larutan dengan penambahan asam tartrat 5 ppm sehingga proporsi $\mathrm{FeCO}_{3}$ mengalami perubahan.

2. Adanya kandungan natrium dan klorid dalam kristal sehingga berpengaruh komposisi kristal.

\section{KESIMPULAN}

Berdasarkan hasil penelitian dan pembahasan yang telah diuraikan dapat disimpulkan bahwa:

1. Penambahan zat aditif asam tartrat $5 \mathrm{ppm}$ memiliki pengaruh yang cukup besar menurunkan pembentukan massa kerak $\mathrm{FeCO}_{3}$. Penambahan aditif asam tartrat 5 ppm mampu mengurangi massa kerak $\mathrm{FeCO}_{3}$ sebesar 15.5\%.

2. Hasil pengujian waktu induksi, Waktu induksi untuk tanpa penambahan adalah 28 menit dengan nilai konduktivitas $8660 \mu \mathrm{S} / \mathrm{cm}$ sedangkan penambahan asam tartrat 5 ppm memiliki waktu induksi 36 menit dengan nilai konduktivitas sebesar $8660 \mu \mathrm{S} / \mathrm{cm}$.

3. Dari hasil SEM antara tanpa penambahan dan dengan penambahan asam tartrat 5 ppm mengalami perubahan pada morfologi siderit. Untuk analisa EDX dihasilkan analisa komposisi atom $\mathrm{Fe}, \mathrm{C}$ dan $\mathrm{O}$. Hal tersebut karena aditif mampu menempel pada permukaan kristal $\mathrm{FeCO}_{3}$ selama proses pertumbuhan kristal sehingga berdampak pada perubahan morfologi kristal $\mathrm{FeCO}_{3}$.

\section{DAFTAR PUSTAKA}

Basim O. Hasan, Graham J. Nathan, Peter J. Ashman, Richard A. C. 2012. The Effects of temperature and Hydrodynamics on The Crystallization Fouling Under Cross Flow conditions, Journal aplied Thermal Engineering. Volume, $36: 210-218$ 
Gourdon. 2011. The Effects of Flow Velocity on Crystallization Fouling in Falling FilmBlack Liquor Evaporators. Proceeding of International Conference on Heat Exchanger Fouling and Cleaning, $4: 23-30$

Hisyam, 2013. Pembentukan kerak kalsium karbonat (caco3) di dalam pipa beraliran laminer pada laju alir $30 \mathrm{ml} /$ menit hingga $50 \mathrm{ml} /$ menit dan penambahan aditif. In Prosiding Seminar Nasional Sains Dan Teknologi Fakultas Teknik (Vol. 1, No. 1).

Holysz, L., Szczes, A., Chibowski, E. (2007). Effects of a static magnetic field on water and electrolyte solutions. Journal of Colloid and Interface Science,316(2), 996-1002.

Isopescus, R., Mateescu, C., Mihai, M., Dabija, G. (2010). The effects of organic additives on induction time and characteristics of precipitated calcium carbonate. Chemical Engineering Research and Design,88, 1450-1454.

J. Hernandez, A. Muñoz and J. Genesca, 2012. Formation of iron-carbonate scalelayer and corrosion mechanism of API X70 pipeline steel in carbon dioxidesaturated 3\% sodium chloride. AfinidAd LXiX, 560

Lilian R. M. F., Haroldo A. P., Luciana S. S., Ana C. T., 2015. CO2 Corrosion in the Region Between the Static and Turbulent Flow Regimes. Materials Research. 2015; 18(2): 245-249

Ma'mun, H., Bayuseno, A. P., Muryanto, S. (2013). Pembentukan kerak kalsium karbonat (caco3) di dalam pipa beraliran laminer pada laju alir $30 \mathrm{ml} / \mathrm{menit}$ hingga $50 \mathrm{ml} / \mathrm{menit}$ dan penambahan aditif asam malat. In Prosiding Seminar Nasional Sains Dan Teknologi Fakultas Teknik (Vol. 1, No. 1).

Mullin J.W. 2004. Crystallization. Butterworth Heinemann : Boston, MA. 280:185198.

Muryanto, S., Bayuseno, A. P., Ma'mun, H., Usamah, M. (2014). Calcium carbonate scale formation in pipes: effect of flow rates, temperature, and malic acid as additives on the mass and morphology of the scale.Procedia Chemistry, 9, 6976.

Omkar A. Nafday, Srdjan N., 2005. IRON CARBONATE SCALE FORMATION AND CO2 CORROSION IN THE PRESENCE OF ACETIC ACID. Institute for Corrosion and Multiphase Technology, Ohio University, No. 05295 
Rabizadeh, T., Caroline., Reacock, Liane G. B. 2014. Carboxilic acid : Effective for Calcium Sulfate Precipitation. Mineralogical

Raharjo S. Muryanto S., J. Jamari, A.P Bayuseno, 2016, 'Modeling and optimization of $\mathrm{CaCO}_{3}$ precipitated from laminar-flow water in the presence of citric acid at an elevated temperature', International Journal of Applied Engineering Research, Vol 11 (15), pp: 8533-8539.

Raharjo S., A.P. Bayuseno, , J. Jamarib, M. Muryanto, S., 2016, 'Calcium carbonate scale formation in copper pipes on laminar flow', Matec web of conferences, $58,01029$.

Ratna, P., S. (2011), Studi Penanggulangan Problem Scale Dari Near-Wellbore Hingga Flowline di Lapangan Minyak Limau, Fakultas Teknik UI, Depok.

Rehan Anthony De Motte, 2016. A Combined Experimental and Modelling Approach to Elucidate FeCO3 Scale Formation Kinetics. Disertation. The University of Leeds Institute of Functional Surfaces, iFS School of Mechanical Engineering.

S. Raharjo, S. Muryanto, J. Jamari and A. P. Bayuseno, 2016, 'Optimization of Calcium Sulfate Precipitated in the Laminar Flow Pipe through Response Surface Modeling of Temperature, $\mathrm{Ca}^{2+}$ Concentration and Citric acid Additives', Oriental Journal of Chemistry, ISSN 0970-020 X, Vol 32 (6), pp: 3145-3154.

Saeid K., Mokhtar C. I., Bothi R., Hamed M., Seyed S. E., Majid M., 2016. Formation of Nano-Scale FeCO3 Protective Corrosion Product in Carbon Dioxide-Saturated 3\% Sodium Chloride Solution. Engineering Materials, ISSN: 1662-9795, Vol. 740, pp 3-8

Samsudi et al., 2016. Coulding CaCO3 Scale deposion on the pump system lamunaif art low audition of citive acids. BISTECH, 2016.

Sediono, W., Bayuseno, A. P., Muryanto, S. (2011). Eksperimen Pembentukan Kerak Gipsum Dengan Konsentrasi Ca2+: 3500 Ppm Dan Aditif Fe2+. Momentum, 7(2).

Siswoyo, Erna, K. (2005), Identifikasi Pembentukan Scale, Jurusan Teknik Perminyakan, Fakultas Teknologi Mineral, UPN Veteran Yogyakarta. 
Tzotzi, C., Pahiadaki, T., Yiantsios, S.G., Karabelas, A.J., Andritsos, N. (2007). A study of $\mathrm{CaCO} 3$ skala formation and inhibition in $\mathrm{RO}$ and $\mathrm{NF}$ membrane processes. Journal of Membrane Science,296(1), pp.171-184.

Winia F., Tor H., Tonje B., Patrick R., 2012. Effect of Precorrosion and Temperature on the Formation Rate of Iron Carbonate Film. Pipeline technology conference.

PENULIS:

\section{RIZKI NOVIANTO}

Teknik Mesin Universitas Muhammadiyah Semarang

Email : Kikyizzy96@gmail.com 